\title{
The genera Canomaculina and Parmotrema (Parmeliaceae, Lichenized Ascomycota) in Curitiba, Paraná State, Brazil
}

\author{
SIONARA ELIASARO ${ }^{1,2}$ and CRISTINE G. DONHA ${ }^{1}$
}

(received: October 2, 2002; accepted: March 19, 2003)

\begin{abstract}
The genera Canomaculina and Parmotrema (Parmeliaceae, Lichenized Ascomycota) in Curitiba, Paraná State, Brazil). The present study describes the species of Canomaculina Elix \& Hale and Parmotrema A. Massal. occuring in Curitiba, Paraná. Identification keys, descriptions of the species, and comments are presented. Canomaculina conferenda (Hale) Elix, Canomaculina pilosa (Stizemb.) Elix \& Hale, Parmotrema catarinae Hale and Parmotrema eciliatum (Nyl.) Hale are reported for the first time to Paraná State.
\end{abstract}

Key words - Brazil, Curitiba, lichens, Paraná, Parmeliaceae

RESUMO - (Os gêneros Canomaculina e Parmotrema (Parmeliaceae, Ascomycota Liquenizados) em Curitiba, Estado do Paraná, Brasil). Este estudo descreve as espécies dos gêneros Canomaculina Elix \& Hale e Parmotrema A. Massal. ocorrentes em Curitiba, Paraná. São apresentadas chaves de identificação, descrições e comentários sobre as espécies. Canomaculina conferenda (Hale) Elix, Canomaculina pilosa (Stizemb.) Elix \& Hale, Parmotrema catarinae Hale e Parmotrema eciliatum (Nyl.) Hale são citadas pela primeira vez para o Estado do Paraná.

Palavras-chave - Brasil, Curitiba, liquens, Paraná, Parmeliaceae

\section{Introduction}

The lichen flora of Curitiba, a city that has 21 million $\mathrm{m}^{2}$ of parkland maintained within the urban perimeter (Curitiba 2002), although abundant and diversified, has not yet been systematically surveyed. It is mainly constituted by Parmeliaceae, a family with more than 60 genera and approximate 1000 species (Elix 1994). In Curitiba, the Parmeliaceae are represented by the following 13 genera: Bulbothrix Hale, Canomaculina Elix \& Hale, Canoparmelia Elix \& Hale, Flavoparmelia Hale, Hypotrachyna (Vain.) Hale, Myelochroa (Asahina) Elix \& Hale, Parmelinella Elix \& Hale, Parmelinopsis Elix \& Hale, Parmotrema A. Massal., Punctelia Krog, Relicina (Hale \& Kurok.) Hale, Rimelia Hale \& A. Fletcher and Xanthoparmelia (Vain.) Hale (Eliasaro \& Donha, unpublished data).

The genera Canomaculina Elix \& Hale and Parmotrema A. Massal. are richly represented in Curitiba. Canomaculina is a corticolous, rarely saxicolous genus, comprising 18 species (Crespo \& Cubero 1998), with the major centres of distribution in South America and Africa (Elix 1993). It is characterised by effigurate maculate upper surface and

\footnotetext{
1. Universidade Federal do Paraná, Departamento de Botânica, Laboratório de Liquenologia, Caixa Postal 19031, 81531-970 Curitiba, PR, Brasil.

2._Autor para correspondência: sionara@bio.ufpr.br
}

dimorphous rhizines, that are absent in the closely related genera Parmotrema and Rimelia. Parmotrema is a genus characterised by large thalli with broad lobes, commonly with a broad erhizinate marginal zone on the lower surface and the upper surface usually emaculate or if maculatae, the maculae neither effigurate nor reticulate (Elix 1993). It is best developed in tropical regions where over 300 species are known (Elix 1993).

The objective of this work was to survey the species of the genera Canomaculina and Parmotrema in Curitiba, to characterise them and provide means for their identification.

\section{Material and methods}

Curitiba, the capital of Paraná is located in the south Brazil (25'25'48" S and 49 $\left.9^{\circ} 16^{\prime} 15^{\prime \prime} \mathrm{W}\right)$ and has an area of $432 \mathrm{~km}^{2}$ (Curitiba 2002). Its climate has been characterised as subtropical with fresh summers, frequent freezing weather during the winter, a mean annual precipitation between 1300 and $1500 \mathrm{~mm}$, without dry season (Maack 1981).

The specimens studied were mostly collected by the authors from a variety of places as parks, woodland, avenues and streets in Curitiba, and are deposited in the Herbarium of the Federal University of Parana (UPCB). Herbarium specimens were examined with a dissecting microscope for morphological characterisation. Apothecia and pycnidia were cut by hand with a razor blade and observed under light microscope. Spot tests on upper cortex and medulla were 
carried out with reagents $\mathrm{K}(10 \% \mathrm{KOH}), \mathrm{C}(30 \%$ Potassium hypochlorite) and $\mathrm{K}$ followed by $\mathrm{C}(\mathrm{KC})$, occasionaly the medulla were examined under UV light. Lichen substances were identified by thin layer chromatography according to the methods standardized for lichen products (Culberson \& Ammann 1979, Elix \& Ernst-Russel 1993). Merck's silica gel $60 \mathrm{~F}_{254}$ aluminium plates were developed in solvent $\mathrm{C}$ (Culberson \& Ammann 1979).

\section{Results and Discussion}

Canomaculina Elix \& Hale, Mycotaxon 29:239. 1987.

The genera Canomaculina is represented by seven species in Curitiba. Excluding C. conferenda, a locally rare species, they are found on barks in well lit places, including trees used in arborization near downtown.

Key to the species of Canomaculina occuring in Curitiba

1. Thallus lacking soredia

2. Lower surface mostly black

C. consors

2. Lower surface pale tan to brown

3. Medulla $\mathrm{K}+$ yellow then red (salazinic acid) C. subcaperata

3. Medulla $\mathrm{K}-, \mathrm{KC}+$ rose (norlobaridone and loxodin)

C. recipienda

1. Thallus sorediate

4. Lower surface mostly black

5. Medulla $\mathrm{K}+$ yellow (stictic acid)

5. Medulla KC. muelleri

4. Lower surface pale tan to brown

6. Medulla $\mathrm{K}+$ yellow then red (salazinic acid)

6. Medulla KC. subsumpta C. conferenda

Canomaculina conferenda (Hale) Elix, Mycotaxon 65:477. 1997.

Parmotrema conferendum Hale, Mycotaxon 5:433. 1977.

Thallus adnate, 3-6 $\mathrm{cm}$ wide. Lobes subirregular, apically rounded, 5-10 mm wide, densely ciliate; cilia simple. Upper surface greenish-grey, white effiguratemaculate, submarginally sorediate; soralia at first punctiform, then orbicular, confluent at maturity. Medulla white. Lower surface pale tan to brown, moderate to densely rhizinate; rhizines brown to black, of two types, either thick and up to $5 \mathrm{~mm}$ long or thin and less than $1 \mathrm{~mm}$ long, simple or rarely branched. Apothecia and pycnidia not seen. Chemistry: Cortex $\mathrm{K}+$ yellow (atranorin); medulla $\mathrm{K}-, \mathrm{C}-, \mathrm{KC}+$ rose (norlobaridone and loxodine).

Specimens studied: BRASIL: PARANÁ: Curitiba, Cidade Industrial de Curitiba, Parque dos Tropeiros, 23-III-1999, C. G. Donha 388, 390 (UPCB).

Canomaculina conferenda is here recorded for the first time for Paraná. It is an apparently rare species in Curitiba, where it was collected on a tree trunk in the most industrializated region of the city. It is characterised by the laminal soredia and the presence of norlobaridone and loxodine in the medulla.
Canomaculina consors (Nyl.) Elix \& Hale, Mycotaxon 29:239. 1987.

Parmelia consors Nyl., Flora 68:613. 1885.

Thallus adnate, 4-10 $\mathrm{cm}$ wide. Lobes subirregular, 5-10 mm wide, margins densely ciliate; cilia simple or commonly furcate. Upper surface greenish-grey with white, effigurate macules; vegetative propagules lacking. Medulla white. Lower surface mostly black, moderately rhizinate; rhizines of two types, either thick and up to $5 \mathrm{~mm}$ long, or thin, less than $1 \mathrm{~mm}$ long, intermixed, simple, furcate or rarely squarrosely branched. Apothecia substipitate, 2-5 mm diameter, disc brown, imperforate or perforate; ascospores ellipsoid to subglobose, $14-16 \times 8-10 \mu \mathrm{m}$. Pycnidia not seen. Chemistry: Cortex $\mathrm{K}+$ yellow (atranorin); medulla K-, C-, KC- (aliphatic acids).

Specimens studied: BRASIL: PARANÁ: Curitiba, UFPR, Centro Politécnico, 8-IV-1999, C.G. Donha 476 (UPCB); Parque General Iberê de Mattos, 8-XI-1998, S. Eliasaro 2100 (UPCB); Cidade Industrial de Curitiba, Parque dos Tropeiros, 23-III-1999, C.G. Donha 434 (UPCB).

Canomaculina consors is a locally common corticolous species found in well lit places. It is characterised by the absence of vegetative propagules 
and the negative results for medullary tests (presence of aliphatic acids).

Canomaculina muelleri (Vain.) Elix \& Hale, Mycotaxon 29:240. 1987.

Parmelia muelleri Vain., Acta Soc. Fauna et Fl. Fenn. 7:49. 1890.

Thallus adnate, $5-10 \mathrm{~cm}$ wide. Lobes subirregular, apically rounded, 5-10 mm wide, densely ciliate; cilia tapered, simple or commonly furcate. Upper surface greenish-grey, white effigurate-maculate, submarginally sorediate; soralia at first punctiform, then orbicular, confluent at maturity. Medulla white. Lower surface mostly black, moderate to densely rhizinate to the margins, or with a brown, bare or papillate marginal zone under the lobe apices; rhizines black, of two types, either thick and up to $5 \mathrm{~mm}$ long or thin and less than $1 \mathrm{~mm}$ long, simple, furcate or rarely squarrosely branched. Apothecia and pycnidia not seen. Chemistry: Cortex $\mathrm{K}+$ yellow (atranorin); medulla $\mathrm{K}+$ yellow, $\mathrm{C}$-, KC- (stictic acid).

Specimens studied: BRASIL: PARANÁ: Curitiba, Cidade Industrial de Curitiba, Bosque do Trabalhador, 24-III-1999, C.G. Donha 458 (UPCB); Bairro São Francisco, 29-X-1998, C.G. Donha 256 (UPCB).

Canomaculina muelleri is a scattered corticolous species in parks and streets. It is characterised by the sorediate upper cortex and the presece of stictic acid in the medulla. It is morphologically similar to C. pilosa, and differs only in the medullary chemistry (aliphatic acids in C. pilosa).

Canomaculina pilosa (Stiz.) Elix \& Hale, Mycotaxon 29:240. 1987.

Parmelia pilosa Stiz., Ber. Tätigk. St. Gallischen Naturwiss. Ges. 1888:165. 1890.

Thallus adnate to loosely adnate, $5-10 \mathrm{~cm}$ wide. Lobes subirregular, apically rounded, 5-10 mm wide, densely ciliate; cilia tapered, simple or commonly furcate. Upper surface greenish-grey, white effiguratemaculate, submarginally sorediate; soralia orbicular, confluent at maturity. Medulla white. Lower surface mostly black, moderate to densely rhizinate; rhizines black, of two types, either thick and up to $5 \mathrm{~mm}$ long or thin and less than $1 \mathrm{~mm}$ long, simple or furcate. Apothecia and pycnidia not seen. Chemistry: Cortex $\mathrm{K}+$ yellow (atranorin); medulla K-, C-, KC- (aliphatic acids).
Selected specimens studied: BRASIL: ParanÁ: Curitiba, Bosque Alemão, 15-X-1998, C.G. Donha 155 (UPCB); UFPR, Centro Politécnico, 1-II-1994, S. Eliasaro 1160 (UPCB); Parque General Iberê de Mattos, 8-XI-1998, S. Eliasaro 2099 (UPCB); Cidade Industrial de Curitiba, Parque dos Tropeiros, 23-III-1999, C.G. Donha 427 (UPCB).

Canomaculina pilosa, the most common species of Canomaculina in Curitiba, is here cited for the first time for Paraná State. It is found on trunks and branches of trees in open woodland, streets, avenues and parks. The sorediate upper cortex and the negative results for medullary tests characterise this species.

Canomaculina recipienda (Nyl.) Elix, Mycotaxon 65:477. 1997.

\section{Parmelia recipienda Nyl., Flora 68:609. 1885.}

Thallus loosely adnate, $6-10 \mathrm{~cm}$ wide. Lobes subirregular, apically rounded, 5-20 mm wide, moderate to densely ciliate; cilia simple or rarely branched. Upper surface greenish-grey, white effigurate-maculate; vegetative propagules lacking. Medulla white. Lower surface pale tan to brown near centre, densely rhizinate; rhizines black, of two types, either thick and up to $5 \mathrm{~mm}$ long or thin and less than $1 \mathrm{~mm}$ long, simple. Apothecia and pycnidia not seen. Chemistry: Cortex $\mathrm{K}+$ yellow (atranorin); medulla $\mathrm{K}-, \mathrm{C}-, \mathrm{KC}+$ rose (norlobaridone and loxodine).

Specimens studied: BRASIL: PARANÁ: Curitiba, Parque Regional do Iguaçú Zoológico, 16-XII-1998, S. Eliasaro \& C.G. Donha 282 (UPCB); Bosque Alemão, 15-X-1998, C.G. Donha 143 (UPCB); UFPR, Centro Politécnico, 8-IV-1999, C.G. Donha 474 (UPCB); Cidade Industrial de Curitiba, Parque dos Tropeiros, 23-III-1999, C.G. Donha 391 (UPCB).

Canomaculina recipienda is a locally common corticolous species on barks in open woodland, parks and streets. It is characterised by the absence of vegetative propagules and the presence of loxodine and norlobaridone in the medulla.

Canomaculina subcaperata (Kremp.) Elix, Mycotaxon 65:477. 1997.

Parmelia subcaperata Kremp., Vidensk. Meddel. Dansk Naturhist. Foren. Kjøbenhavn 25:10. 1874.

Thallus loosely adnate, $8-12 \mathrm{~cm}$ wide. Lobes subirregular, apically rounded, 5-20 mm wide, densely ciliate; cilia simple or branched. Upper surface greenish- 
grey, white effigurate-maculate; vegetative propagules lacking. Medulla white. Lower surface pale brown to dark brown near centre, densely rhizinate; rhizines black, of two types, either thick and up to $5 \mathrm{~mm}$ long or thin and up to $0.5 \mathrm{~mm}$ long, simple. Apothecia and pycnidia not seen. Chemistry: Cortex $\mathrm{K}+$ yellow (atranorin), medulla $\mathrm{K}+$ yellow then red, $\mathrm{C}-$, $\mathrm{KC}$ (salazinic acid).

Specimens studied: BRASIL: Paraná: Curitiba, Parque Regional do Iguaçú Zoológico, 16-XII-1998, S. Eliasaro \& C.G. Donha 333 (UPCB); Bairro Cristo Rei, 23-VI-1998, S. Eliasaro 1987 (UPCB).

Canomaculina subcaperata is an uncommon species on barks in open woodland, streets and parks. The absence of vegetative propagules and the presence of salazinic acid in the medulla characterise this species.

Canomaculina subsumpta (Nyl.) Elix, Mycotaxon 65:477. 1997.

\section{Parmelia subsumpta Nyl., Flora 52:117. 1869.}

Thallus loosely adnate, $5-10 \mathrm{~cm}$ wide. Lobes subirregular, apically rounded, 5-18 mm wide, moderate to densely ciliate; cilia simple or branched. Upper surface greenish-grey, white effigurate-maculate; sorediate; soralia marginal or submarginal, linear to subcapitate, coalescing at maturity. Medulla white.
Lower surface pale tan to brown near centre, densely rhizinate; rhizines black, of two types, either thick and up to $5 \mathrm{~mm}$ long or thin and less than $1 \mathrm{~mm}$ long, simple. Apothecia and pycnidia not seen. Chemistry: Cortex $\mathrm{K}+$ yellow (atranorin); medulla $\mathrm{K}+$ yellow then red, $\mathrm{C}$ (salazinic acid).

Specimens studied: BRASIL: PARANÁ: Curitiba, Parque Regional do Iguaçú Zoológico, 16-XII-1998, S. Eliasaro \& C.G. Donha 331 (UPCB); Bairro Bacacheri, Conjunto Solar, 29-VI-1998, C.G. Donha 85 (UPCB); Bairro Cristo Rei, 23-VI-1998, S. Eliasaro 1989 (UPCB).

Canomaculina subsumpta is a scattered species growing on barks in open woodland, streets and parks. It is characterised by the pale brown lower surface, the submarginal or marginal soralia and the presence of salazinic acid in the medulla.

Parmotrema A. Massal., Atti Reale Ist. Veneto Sci. Lett. Arti, ser. 3, 5:248. 1860.

The genera Parmotrema is represented by 14 species in Curitiba. P. austrosinense, P. permutatum and $P$. tinctorum were found near dowtown and on trees along avenues, while the commonest species $P$. chinense and $P$. internexum are limited to less urbanizated places. $P$. flavomedulosum, $P$. robustum, $P$. schindleri and $P$. xanthinum occurs only in parks with native vegetation.

Key to the species of Parmotrema occuring in Curitiba

1. Thallus without soredia and isidia

2. Medulla $\mathrm{C}+$ rose (gyrophoric acid)

P. catarinae

2. Medulla C-

3. Medulla $\mathrm{K}+$ yellow (stictic acid) P. eciliatum

3. Medulla KP. melanothrix

1. Thallus sorediate or isidiate

4. Thallus sorediate

5. Medulla mostly orange or pale yellow

6. Eciliate to rarely sparingly ciliate P. flavomedullosum

6. Moderately to densely ciliate P.permutatum

5. Medulla white

7. Medulla $\mathrm{C}+$ red or rose

8. Marginal cilia absent, lecanoric acid present

$P$. austrosinense

8. Marginal cilia present, gyrophoric acid present

P. sancti-angeli

7. Medulla C-

9. Medulla $\mathrm{K}+$ yellow (stictic acid).

P. chinense

9. Medulla K-

10. Densely ciliate; cilia $1-3 \mathrm{~mm}$ long, soralia submarginal to rarely laminal. P. schindleri

10. Eciliate to sparingly ciliate; cilia up to $1 \mathrm{~mm}$ long; soralia marginal and linear along margins to subcapitate on marginal laciniae 
4. Thallus isidiate

11. Upper cortex yellow-green, K- (usnic acid)

P. xanthinum

11. Upper cortex pale grey to grey-green, $\mathrm{K}+$ yellow (atranorin)

12. Medulla $\mathrm{C}+$ red (lecanoric acid)

P. tinctorum

12. Medulla C-

13. Medulla $\mathrm{K}+$ yellow, UV- (stictic acid)

P. internexum

13. Medulla K-, UV+ white-blue (alectoronic acid) P. mellissii

Parmotrema austrosinense (Zahlbr.) Hale, Phytologia 28(4):335. 1974.

Parmelia austrosinensis Zahlbr., Symb. Sin. :192. 1930.

Thallus loosely adnate, $5-8 \mathrm{~cm}$ wide. Lobes rounded, 10-30 $\mathrm{mm}$ wide, margins often ascending, eciliate. Upper surface pale grey to grey-green, emaculate to faintly maculate; sorediate; soralia marginal to submarginal, linear. Medulla white. Lower surface black in the centre, with a brown erhizinate marginal zone, sparsely rhizinate; rhizines simple, black. Apothecia and pycnidia not seen. Chemistry: Cortex $\mathrm{K}+$ yellow (atranorin); medulla $\mathrm{K}-, \mathrm{C}+$ red, $\mathrm{KC}+$ red (lecanoric acid).

Specimens studied: BRASIL: PARANÁ: Curitiba, Bosque Alemão, 15-XI-1998, C.G. Donha 165 (UPCB); UFPR, Centro Politécnico, 8-IV-1999, C.G. Donha 478 (UPCB); Cidade Industrial de Curitiba, Parque dos Tropeiros, 23-III-1999, C.G. Donha 401 (UPCB).

Parmotrema austrosinense is relatively common in Curitiba. It occurs on tree trunks in well lit sites. It is characterised by the eciliate lobes, often with ascending margins, marginal to submarginal soralia and the presence of lecanoric acid in the medulla.

Parmotrema catarinae Hale, Mycotaxon 25:87. 1986.

Thallus loosely adnate, $5-8 \mathrm{~cm}$ wide. Lobes rounded, $10-30 \mathrm{~mm}$ wide, margins ascending, moderately ciliate; cilia $2-4 \mathrm{~mm}$ long, simple or branched. Upper surface pale grey to grey-green, emaculate to faintly maculate; vegetative propagules lacking. Medulla white. Lower surface black in the centre, with a white to brown erhizinate marginal zone, sparsely rhizinate; rhizines simple to sparsely branched, black. Apothecia and pycnidia not seen. Chemistry: Cortex K+ yellow (atranorin); medulla $\mathrm{K}-, \mathrm{C}+$ rose, $\mathrm{KC}+$ rose (gyrophoric acid).

Specimens studied: BRASIL: PARANÁ: Curitiba, UFPR, Centro Politécnico, 8-IV-1999, S. Eliasaro 1173 (UPCB); Cidade Industrial de Curitiba, Parque dos Tropeiros, 23-III-1999, C.G. Donha 406 (UPCB).
This is the first report of Parmotrema catarinae for Paraná State. It is an uncommon species on tree trunks in parks. The absence of vegetative propagules and the presence of gyrophoric acid in the medulla characterise this species.

Parmotrema chinense (Osbeck) Hale \& Ahti, Taxon 35:133. 1986.

Lichen chinenis Osbeck, Dagb. Ostind. resa:221. 1757.

Thallus loosely to moderately adnate, $4-10 \mathrm{~cm}$ wide. Lobes rounded to irregularly incised, $6-15 \mathrm{~mm}$ wide, margins crenate, sparsely to moderately ciliate; cilia 1-2 mm long, simple or branched. Upper surface pale grey to grey-green, emaculate; sorediate; soralia marginal to submarginal, linear to subcapitate, sorediate lobes becoming revolute, soredia granular. Medulla white. Lower surface black in the centre, with a brown erhizinate marginal zone, moderately rhizinate; rhizines simple to sparsely branched, black. Apothecia and pycnidia not seen. Chemistry: Cortex $\mathrm{K}+$ yellow (atranorin); medulla $\mathrm{K}+$ yellow, $\mathrm{C}-$, $\mathrm{KC}$ - (stictic acid, constictic acid, menegazziaic acid).

Specimens studied: BRASIL: PARANÁ: Curitiba, Parque Regional do Iguaçú Zoológico, 16-XII-1998, S. Eliasaro \& C.G. Donha 312 (UPCB); Bosque Alemão, 15-X-1998, C.G. Donha 149 (UPCB); UFPR, Centro Politécnico, 15-IX-1993, S. Eliasaro 1069 (UPCB); Parque Passaúna, 1-VII-1998, C.G. Donha 108 (UPCB); Parque Tanguá, 1-VII-1998, C.G. Donha 94 (UPCB).

It is a very common species on bark in open woodlands and parks. The presence of stictic acid in the medulla distinguish Parmotrema chinense from all other sorediate species of Parmotrema in Curitiba.

Parmotrema eciliatum (Nyl.) Hale, Phytologia 28:336. 1974.

Parmelia crinita Ach. var. eciliata Nyl., Flora 52:291. 1869.

Thallus loosely adnate, $5-8 \mathrm{~cm}$ wide. Lobes 
irregular, 5-15 mm wide, margins crenate, sparsely ciliate; cilia up to $1 \mathrm{~mm}$ long, simple. Upper surface pale grey to grey-green, emaculate; vegetative propagules lacking. Medulla white. Lower surface black in the centre, with a brown erhizinate marginal zone, densely rhizinate; rhizines simple to branched, black. Apothecia and pycnidia not seen. Chemistry: Cortex $\mathrm{K}+$ yellow (atranorin); medulla $\mathrm{K}+$ yellow, $\mathrm{C}-, \mathrm{KC}-$ (stictic acid, constictic acid, unidentified compounds).

Specimens studied: BRASIL: PARANÁ: Bosque Alemão, 15-X-1998, C.G. Donha 151 (UPCB); UFPR, Centro Politécnico, 2-X-1995, M. Bündchen 123(UPCB); Parque Tanguá, 1-VII-1998, C.G. Donha 103 (UPCB).

Parmotrema eciliatum is here recorded for the first time to Paraná. It is a scattered species found on trunks and branches in parks. It is characterised by the absence of vegetative propagules and the presence of stictic acid in the medulla.

Parmotrema flavomedullosum Hale, Mycotaxon 1:110. 1974.

Thallus adnate, $6-12 \mathrm{~cm}$ wide. Lobes rounded, 10-20 mm wide, margins entire to crenate, eciliate to rarely sparingly ciliate; cilia in lobe axils, less than $1 \mathrm{~mm}$ long, simple. Upper surface pale grey to greygreen, emaculate, cortex fragile near lobe margins; sorediate; soralia marginal to submarginal, pustular and punctiform or spreading and becomig confluent, soredia granular. Medulla yellow to orange. Lower surface black in the centre, with a brown erhizinate marginal zone, sparsely rhizinate; rhizines simple, black. Apothecia and pycnidia not seen. Chemistry: Cortex $\mathrm{K}+$ yellow (atranorin); medulla $\mathrm{K}-\mathrm{C}+$ rose, $\mathrm{KC}+$ rose (gyrophoric acid, unidentified compounds).

Specimens studied: BRASIL: Paraná: Curitiba, Parque Regional do Iguaçú Zoológico, 16-XII-1998, S. Eliasaro \& C.G. Donha 289, 295 (UPCB).

Parmotrema flavomedullosum is a locally rare species found only on bark of trees in a coppice of Araucaria Forests. It is characterised by the yellow to orange medulla, ecilate to rarely ciliate lobes and by the fragile upper cortex. P. permutatum is superficially similar, but has ciliate margins and marginal and linear soralia.

Parmotrema internexum (Nyl.) Hale ex De Priest \& B. Hale, Mycotaxon 67:204. 1998.

\section{Parmelia internexa Nyl., Flora 68:609. 1885.}

Thallus adnate, 7-10 cm wide. Lobes rounded, 5-15 mm wide, margins entire to crenate, eciliate or with short cilia in lobe axils. Upper surface grey-green, emaculate, densely isidiate; isidia laminal and marginal, simple to rarely branched, brown-tipped, eciliate. Medulla white. Lower surface black in the centre, with a brown to ivory erhizinate marginal zone, moderate to densely rhizinate; rhizines simple to rarely branched, black. Apothecia rare, 2-4 mm wide, disc imperforate, thalline exciple isidiate; ascospores 22-26 $\times 10-15 \mu \mathrm{m}$. Pycnidia not seen. Chemistry: Cortex $\mathrm{K}+$ yellow (atranorin); medulla $\mathrm{K}+$ yellow, $\mathrm{C}-, \mathrm{KC}$ - or $\mathrm{KC}+$ lilac, UV- (stictic acid, constictic acid, sometimes norlobaridone and loxodin).

Specimens studied: BRASIL: PARANÁ: Curitiba, Parque Regional do Iguaçú Zoológico, 16-XII-1998, S. Eliasaro \& C.G. Donha 270, 328 (UPCB); Bosque Alemão, 15-X-1998, C.G. Donha 104b (UPCB); UFPR, Centro Politécnico, 27-I-1999, C.G. Donha 337 (UPCB); Parque dos Tropeiros, 23-III-1999, C.G. Donha 336, 404 (UPCB); Bairro Umbará, 10-I-1999, L.T. Maranho s.n. (UPCB).

Parmotrema internexum is one of the commonest Parmeliaceae in Curitiba, ocurring on barks in woodland, parks and streets in less urbanizated areas. The presence of stictic acid in the medulla distinguish this species from all other isidiate Parmotrema in Curitiba.

Parmotrema melanothrix (Mont.) Hale, Phytologia 28(4):337. 1974.

Parmelia urceolata Eschw. var. melanothrix Mont., Ann. Sci. Nat., Bot. ser. 2, 2:372. 1834.

Thallus loosely adnate, 4-7 $\mathrm{cm}$ wide. Lobes rounded, $5-10 \mathrm{~mm}$ wide, margins entire to crenate, ascending, densely ciliate; cilia simple, 2-4 mm long. Upper surface pale grey to grey-green, emaculate; vegetative propagules lacking. Medulla white. Lower surface black in the centre, with a white to ivory erhizinate marginal zone, moderately rhizinate; rhizines simple to rarely branched, black. Apothecia common, 3-8 mm wide, disc imperforate, thalline exciple ciliate; ascospores 19-26 $\times 8-13 \mu \mathrm{m}$. Pycnidia common, conidia filiform, 7-11 $\mu \mathrm{m}$ long. Chemistry: Cortex $\mathrm{K}+$ yellow (atranorin); medulla K-, C-, KC- (protoliquesterinic acid, unidentified fatty acids).

Specimens studied: BRASIL: ParanÁ: Curitiba, UFPR, Centro Politécnico, 8-IV-1999, C. Morales 3 (UPCB); Ópera de Arame, 7-IX-1994, M. Schatzmann 34 (UPCB); Bairro Bacacheri, 29-VI-1998, C.G. Donha 82 (UPCB). 
Parmotrema melanothrix is a scattered species found on tree trunks in parks. The absence of vegetative propagules and the negative results for medullary tests characterise this species .

Parmotrema mellissii (C.W. Dodge) Hale, Phytologia 28:337. 1974.

Parmelia mellissii C. W. Dodge, Ann. Missouri Bot. Gard. 46:134. 1959.

Thallus loosely adnate, $5-9 \mathrm{~cm}$ wide. Lobes rounded, 6-15 $\mathrm{mm}$ wide, margins crenate, ascending, densely ciliate; cilia simple or rarely branched, 1-3 mm long. Upper surface pale grey to grey-green, emaculate, cortex fragile, isidiate; isidia marginal to submarginal, simple to branched, sometimes becoming granular and sorediate. Medulla white. Lower surface black in the centre, with a pale brown to brown erhizinate marginal zone, sparsely rhizinate; rhizines simple to rarely branched, black. Apothecia not seen. Pycnidia rare, conidia filiform, 7-10 $\mu \mathrm{m}$ long. Chemistry: Cortex $\mathrm{K}+$ yellow (atranorin); medulla $\mathrm{K}-, \mathrm{C}-, \mathrm{KC}-$ or $\mathrm{KC}+$ rose, $\mathrm{UV}+$ white blue (alectoronic acid, unidentified compounds).

Specimens studied: BRASIL: PARANÁ: Curitiba, Parque Regional do Iguaçú Zoológico, 16-XII-1998, S. Eliasaro \& C.G. Donha 286(UPCB); UFPR, Centro Politécnico, 25-VI-1998, S. Eliasaro 2005 (UPCB).

Parmotrema melissii is an uncommon species on tree trunks in parks and woodland. The densely ciliate lobes margins, the isidia that becoming sorediate and the presence of alectoronic acid in the medulla characterise this species.

Parmotrema permutatum (Stirt.) Hale, Phytologia 28(4):338. 1974.

Parmelia permutata Stirt., Scott. Naturalist (Perth) 4:252. 1878.

Thallus loosely adnate, $6-10 \mathrm{~cm}$ wide. Lobes rounded, 5-18 $\mathrm{mm}$ wide, margins entire to crenate, moderately to densely ciliate; cilia simple to furcate, up to $1.5 \mathrm{~mm}$ long. Upper surface pale grey to greygreen, emaculate; sorediate; soralia marginal, linear, soredia granular, often grey brown. Medulla yellow to orange-yellow or white in the upper half and yellow in the lower half. Lower surface black in the centre, with a dark brown erhizinate marginal zone, moderately rhizinate; rhizines simple to rarely branched, black. Apothecia and pycnidia not seen. Chemistry: Cortex $\mathrm{K}+$ yellow (atranorin); medulla $\mathrm{K}-, \mathrm{C}+$ rose, $\mathrm{KC}+$ rose (gyrophoric acid, unidentified compounds).

Specimens studied: BRASIL: PARANÁ: Curitiba, UFPR, Centro Politécnico, 8-IV-1999, M. Bündchen 198 (UPCB); Parque General Iberê de Mattos, 8-XI-1998, S. Eliasaro 2098 (UPCB); Centro Cívico, 15-IX-1998, C.G. Donha 182a (UPCB); Bairro Umbará, 22-IX-1998, L.T. Maranho 46 (UPCB); Parque Barigüí, 8-III-1994, S. Eliasaro 1217 (UPCB).

Parmotrema permutatum is a relatively common species in Curitiba. It occurs on trunks and branches in well lit sites, including trees near downtown. It is a sorediate species characterised by the ciliate lobes and the pigmented medulla.

Parmotrema robustum (Degel.) Hale, Phytologia 28(4):338. 1974.

Parmelia robusta Degel., Göteborgs Kungl. Vetensk. Samhälles Handl., Ser. B, Mat. Naturvetensk. Skr., ser. 6, 1:33. 1941.

Thallus loosely adnate, 5-8 cm wide. Lobes rounded, $10-18 \mathrm{~mm}$ wide, margins entire to laciniate, eciliate to sparingly ciliate; cilia simple, up to $1 \mathrm{~mm}$ long. Upper surface pale grey to grey-green, emaculate; sorediate; soralia marginal, linear along margins to subcapitate on short marginal laciniae. Medulla white. Lower surface black in the centre, with a white to ivory erhizinate marginal zone, sparsely rhizinate; rhizines in scattered groups, simple to rarely branched, black. Apothecia and pycnidia not seen. Chemistry: Cortex $\mathrm{K}+$ yellow (atranorin); medulla K-, C-, KC(protocetraric acid).

Specimens studied: BRASIL: PARANÁ: Curitiba, Parque Regional do Iguaçú Zoológico, 16-XII-1998, S. Eliasaro \& C.G. Donha 319 (UPCB).

Parmotrema robustum was found only on bark of trees in a coppice of Araucaria Forests. It is characterised by the ecilate to rarely ciliate lobes, soralia marginal and linear along margins to subcapitate on marginal laciniae and by the presence of protocetraric acid in the medulla. P. schindleri is superficially similar, but has densely ciliate margins and submarginal to laminal soralia.

Parmotrema sancti-angeli (Lynge) Hale, Phytologia 28(4):339. 1974.

Parmelia sancti-angeli Lynge, Ark. Bot. 13:35. 1914.

Thallus loosely to moderately adnate, $4-12 \mathrm{~cm}$ wide. Lobes rounded to irregular, 5-15 mm wide, 
margins entire to crenate, ascending, ciliate; cilia simple to branched, 2-3 mm long. Upper surface pale grey, emaculate; sorediate; soralia marginal, linear, soredia farinose. Medulla white. Lower surface black in the centre, with a brown to dark brown erhizinate marginal zone, sparsely to moderately rhizinate; rhizines simple to rarely branched, black. Apothecia and pycnidia not seen. Chemistry: Cortex $\mathrm{K}+$ yellow (atranorin); medulla $\mathrm{K}-, \mathrm{C}+$ rose, $\mathrm{KC}+$ rose (gyrophoric acid).

Specimens studied: BRASIL: PARANÁ: Parque Passaúna, 1-VII-1998, C.G. Donha 109 (UPCB); UFPR, Centro Politécnico, 9-VII-1993, S. Eliasaro 1017 (UPCB); Parque dos Tropeiros, 23-III-1999, C.G. Donha 425 (UPCB); Bairro Umbará, 12-X-1998, L.T. Maranho $6 b$ (UPCB).

Parmotrema sancti-angeli is a scattered species growing on bark in open woodland, parks and streets in less urbanizated areas. It is characterised by the marginal and linear soralia and the presence of gyrophoric acid in the medulla.

Parmotrema schindleri Hale, Mycotaxon 21(1):89. 1986.

Thallus loosely adnate, $8-12 \mathrm{~cm}$ wide. Lobes rounded, 5-10 mm wide, margins entire to crenate, ascending, densely ciliate; cilia simple to branched, 1-3 mm long. Upper surface grey-green, emaculate or faintly maculate, becoming reticulate-cracked centrally; sorediate; soralia submarginal to rarely laminal, subcapitate, pustular, soredia granular. Medulla white. Lower surface black in the centre, with a brown erhizinate marginal zone, sparsely rhizinate; rhizines simple to branched, black. Apothecia and pycnidia not seen. Chemistry: Cortex K+ yellow (atranorin); medulla K-, C-, KC- (protocetraric acid, unidentified compounds).

Specimens studied: BRASIL: PARANÁ: Curitiba, Parque Regional do Iguaçú Zoológico, 16-XII-1998, S. Eliasaro \& C.G. Donha 288 (UPCB).

Parmotrema schindleri, such as P. flavomedulosum and $P$. robustum, is a locally rare species only found in a coppice of Araucaria Forests. It grows on rock in shaded places. It is characterised by the densely ciliate lobes, the soralia submarginal to laminal and by the presence of protocetraric acid in the medulla.

Parmotrema tinctorum (Nyl.) Hale, Phytologia 28(4):339. 1974.

Parmelia tinctorum Nyl., Flora 55:547. 1872.
Thallus loosely adnate, $7-15 \mathrm{~cm}$ wide. Lobes rounded, 10-20 mm wide, margins entire, eciliate. Upper surface pale grey, emaculate, becoming cracked centrally; moderate to densely isidate; isidia laminal to rarely marginal, confluent or in scattered groups, sometimes brown-tipped, simple to branched. Medulla white. Lower surface black in the centre, with a dark brown erhizinate marginal zone, sparsely rhizinate; rhizines simple to branched, black. Apothecia and pycnidia not seen. Chemistry: Cortex $\mathrm{K}+$ yellow (atranorin); medulla $\mathrm{K}-, \mathrm{C}+$ red, $\mathrm{KC}+$ red (lecanoric acid).

Specimens studied: BRASIL: PARANÁ: Curitiba, Parque Regional do Iguaçú Zoológico, 29-XI-1998, C.G. Donha 258 (UPCB); Centro Cívico, 15-XI-1998, C.G. Donha 168 a (UPCB); Bairro Cristo Rei, 23-IV-1998, S. Eliasaro 1993 (UPCB); Bosque da Fazendinha, 24-III-1999, C.G. Donha 439 (UPCB); Bairro Umbará, 22-IX-1998, L.T. Maranho 39 (UPCB); Parque Barigüí, 8-III-1994, S. Eliasaro 1227 (UPCB).

Parmotrema tinctorum is a locally very common species, found on trunks and branches of trees in open woodland, streets, avenues and parks. It is easily recognised by the eciliate lobes margins, the isidiate upper surface and by the presence of lecanoric acid in the medulla.

Parmotrema xanthinum (Müll. Arg.) Hale, Phytologia 28(4):339. 1974.

Parmelia proboscidea Taylor var. xanthina Müll. Arg., Lichen. bei. 20:7. 1884.

Thallus loosely adnate, 7-12 cm wide. Lobes rounded, $10-15 \mathrm{~mm}$ wide, margins entire to crenate, ciliate; cilia 1-3 mm long, simple to furcate. Upper surface yellow-green, emaculate, becoming reticulatecracked centrally; isidiate; isidia marginal to submarginal, simple to coralloid-branched, browntipped, often ciliate. Medulla white. Lower surface black in the centre, with a dark brown erhizinate marginal zone, moderately rhizinate; rhizines simple to branched, black. Apothecia and pycnidia not seen. Chemistry: Cortex K- (usnic acid); medulla K-, C+, $\mathrm{KC}+$ (gyrophoric acid, unidentified compounds).

Specimens studied: BRASIL: PARANÁ: Curitiba, Parque Tanguá, 1-VII-1998, C.G. Donha 91 (UPCB).

Parmotrema xanthinum is an apparently rare species in Curitiba, where it was collected on exposed rock in a park. The presence of usnic acid in the upper surface distinguish $P$. xanthinum from all other species of Parmotrema in Curitiba. 
Acknowledgments - We thank the MSc Leila T. Maranho for the valuable colecctions from Umbará and Glauco B. Trindade and Nasser K. Hammad for their assistance in the field work.

\section{References}

CRESPO, A. \& CUBERO, O.F. 1998. A molecular approach to the circumscription and evaluation of some genera segregated from Parmelia s. lat. Lichenologist 30:369-380.

CULBERSON, C.F. \& AMMANN, K. 1979. Standarmethode zur Dünnschicht-chromatographie von Flechtensubstanzen. Herzogia 5:1-24.

CURITIBA. 2002 [15 March 2002]. Prefeitura Municipal de Curitiba, a Capital Social, Perfil. http:// www.curitiba.pr.gov.br/pmc.
ELIX, J.A. 1993. Progress in the generic delimitation of Parmelia sensu lato lichens (Ascomycotina: Parmeliaceae) and a synoptic key to the Parmeliaceae. Bryologist 96:359-383.

ELIX, J.A. 1994. Parmeliaceae, key to the genera in Flora of Australia 55 Lichens - Lecanorales 2. In Australian Biological Resources Study (C. Grgurinovic, ed.). (SIRO Publishing) Canberra, p.1-11.

ELIX, J.A., \& ERNST-RUSSELL, J.L. 1993. A catalogue of standardized thin layer crhomatographic data and biosynthetic relationships for lichen substances. $2^{\text {nd }}$ ed., Australian National University, Canberra.

MAACK, R. 1981. Geografia Física do Estado do Paraná. 2a ed., José Olimpio, Rio de Janeiro. 